\title{
Exploratory Practice: A Collaborative and Learning Experience for Both Student and Educator
}

Benjamin L. Stewart y Flor de la Rosa Mireles

$\mathrm{T}$ ransmitir conocimientos es una de las principales labores de un maestro; sin embargo, enseñar a otro a descubrir cómo hacerlo por cuenta propia, aplicando este conocimiento en un contexto real es un reto para cualquiera. La práctica exploratoria $(\mathrm{PE})$ provee una alternativa para la enseñanza y el aprendizaje, permite que el profesor y el estudiante negocien mediante la experiencia educativa, teniendo en mente las necesidades, los intereses y las preferencias de aprendizaje del alumno. Este artículo expone cómo la PE fue empleada en un curso de la Licenciatura en Docencia del Idioma Inglés en la Universidad Autónoma de Aguascalientes. Esta práctica fue utilizada como una alternativa por parte de uno los profesores de esta licenciatura para asistir a una estudiante en el desarrollo de una investigación, colaborando mutuamente en el diseño y análisis de la misma. Además, ambos participantes, desde su concerniente perspectiva, reflexionan sobre las dificultades y enseñanzas, aportando una visión más amplia sobre la experiencia de participar en una PE. Finalmente, las conclusiones apuntan que la PE también es apropiada para aplicarse en cualquier otro curso donde los problemas, situaciones o desafíos proporcionen un contexto significativo y relevante para los estudiantes.

The art of teaching is the art of assisting discovery. Mark Van Doren

Assisting discovery in the classroom is in stark contrast to how content is typically delivered in the classroom. Oftentimes a course syllabus will have a bibliography that lists relevant sources where much of the content for the class can be found. In addition, it is common during the lesson planning process for teachers to present predetermined content to the students before having students actively engage with that content. Perhaps content is too complicated for students to seek out first themselves, requiring teachers to "front-load" information so that students are able to interact with content in some meaningful way. Teachers and students may not feel teachers are doing their jobs if they are not spending adequate amounts of time lecturing in front of the group. However, an alternative approach to this pedagogical paradigm exists that permits a more inquiry -and problembased learning design as a complementary component to one's overall instructional design. Thus, exploratory practice (EP) provides an alternative framework for teaching and learning that allows the educator and learner to negotiate through the educative experience, not only with the learner in mind, but more directly as a result of the learners' needs, interests, and learning preferences.

The EP framework depends on how the educator and learner are able to negotiate around a potential problem and possible solution (i.e., problem setting) that together align with the desired outcomes of the class. Based on the syllabus, an EP framework emerges whereby the teacher and learner adopt and adapt to an overall educative experience. EP was originally defined within the context of language teaching as follows (Allwright and Lenzuen, 1997): 
EP is a name given to a sustainable way of carrying out classroom investigations which provide language teachers (and potentially learners also) with a systematic framework within which to define areas of language teaching that they wish to explore, to refine their thinking about them, and to investigate them further using classroom activities, rather than academic research techniques, as the investigative tools (as cited in Zhang, 2004: 332).

The EP framework is based on seven principles and stem from what, who, and how issues within a given institution or school. According to Allwright and Hanks (2009), the what issues are a) the quality of one's life and b) understanding a problem before solving it; the who issues are a) practitioners together cultivating their own understandings, b) bringing people together, and c) cooperating for reciprocal learning; and the how issues are a) making learning a continuous process and $b$ ) integrating understandings into normal pedagogic practice (as cited in Hanks, 2015). Therefore, implementing the EP framework begins with a problem, issue, or challenge that the student and educator decide on first, which they then continue working on throughout the rest of the course. The learning sequence consists of the educator and student working through the problem while both the educator and student interact with the appropriate content required to address the problem, issue, or challenge. What is unique with the EP framework is how content is delivered. When implementing EP, the learner takes a systematic approach to gathering information (i.e. content) in much the same way a researcher might approach it: conducting a content analysis, applying questionnaires, interviews, etc. The role of the teacher will depend on the readiness level of the learner in terms of collecting the proper data (i.e., content), analyzing the data, and reporting it to a particular audience. In other words, the teacher adapts to the situation by determining on the spot which role is most appropriate: didactic leader, facilitator, or coach. Learners engage with EP, even if they find it challenging at the onset, and often emerge as profound opportunities for learning [emphasis added] (Hanks, 2015).

What follows is an example of how EP was employed during a course that took place during the semester, January - June of 2015. The overall context is presented first which is then followed by the study that the learner performed over a single semester. Reflections follow from both the perspective of the learner and the educator in order to provide further insight into the EP experience. The conclusion suggests that EP is also appropriate for other classroom settings where problems, issues, or challenges provide relevant and meaningful contexts for students.

\section{Context}

The Universidad Autónoma de Aguascalientes (UAA) offers a bachelor's degree program in English language teaching (Licenciatura en Docencia del Idioma Inglés, or LDII) for those who meet the entrance requirements and have an interest in teaching English to speakers of other languages (TESOL). The final semester (i.e., the eighth semester) of study for those enrolled in the LDII program includes a thesis seminar course which entails a research project in the field of applied linguistics. Learners enrolled in thesis seminar are given the opportunity to research a problem of their choosing based on either 1) their own experience as an English language learner or 2) their own experience teaching English to speakers of other languages. Thus, thesis seminar becomes a capstone learning experience that affords the LDII learner an opportunity to demonstrate understandings that link theoretical and practical applications of classroom situations that stem from problems that currently occupy the field of applied linguistics (i.e., the teaching and learning of an additional language).

Thesis seminar is different than a "traditional" class in that students meet more on a oneon-one basis with a tutor once a week. Learners complete a written reflection concerning what they achieved for the week, what they plan on doing the subsequent week, any challenges or problems they face, and any particular points they would like to discuss during their next tutoring session. Google Sites was used to host class announcements, video tutorials, video instructions, weekly reflections, and links to all written work throughout the semester (Stewart, 2015). Moreover, Microsoft Word Online documents were shared between the 


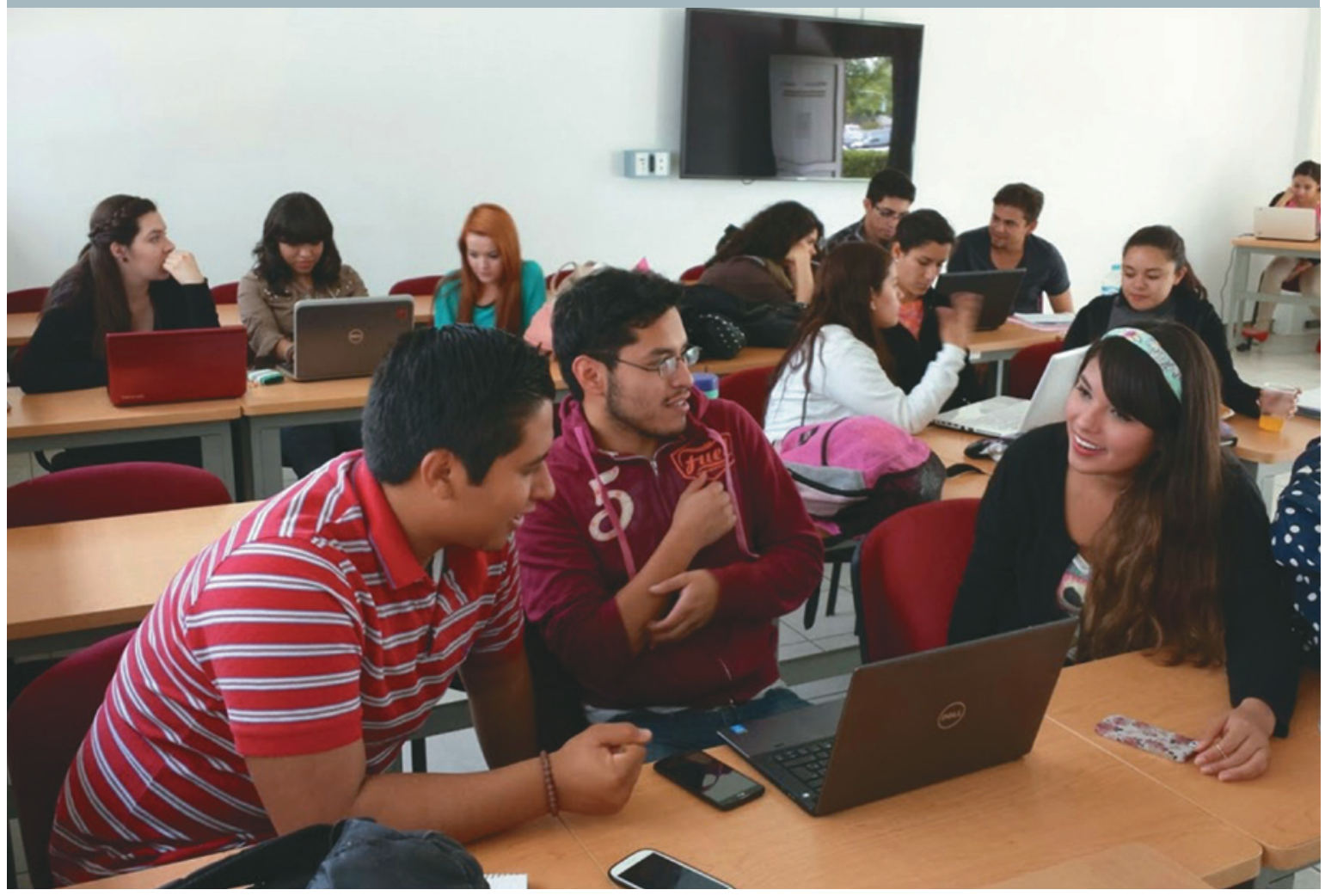

student and tutor as each student document was viewable to the public as well. Because student work was open, students were able to compare what they had with that of their classmates, and all students were able to see all of the feedback received by the entire class. Feedback in the form of the Word commenting system allowed for both teacher and peer assessment throughout the course, which took place either in class or outside of class. Finally, all technologies used in class were free for students.

\section{Student Research as Described by the Student Researcher}

The objective of this study was to identify how an English language teacher implements web 2.0 tools to promote collaborative writing in the classroom. The research questions that guided this study were 1) How do students collaborate with each other using web 2.0 tools to promote the writing skill? and 2) How do students feel about us- ing web 2.0 tools as a way of collaboration? The participants involved in this study were an English language teacher working in the B.A. in English language teaching from the Universidad Autónoma de Aguascalientes and 15 students from a $4^{\text {th }}$ semester composition course designed to assist students to develop and improve writing skills using different web 2.0 tools. In the first week, an observation protocol was used to write down the actions related to the research during the classes in which teams wrote an academic text. In the second week, after the task was completed, an online survey was applied, which was divided into two different sections: one section for questions related to a task performed by students and a second section for general questions about the course. In the third week, guiding questions were created based on the observations and survey responses in order to conduct a focus group with each team. To conclude, an interview with specific questions were asked to the teacher in order to clarify aspects of the task and to know some of his opinions pertaining to the use of web 2.0 tools to promote collaborative learning. 
All of the data collected for this study was subsequently transcribed and coded into themes based on the research questions.

The results of the research showed how students wrote collaboratively using specific web 2.0 tools and developing specific roles. The teacher divided the 15 students into four teams with the purpose of writing an academic text collaboratively. Within the groups, students assigned roles themselves; in the interview, teacher explained that the objective of doing this was to give students the freedom to notice individual and their peers' strengths and weaknesses based on how responsibilities were distributed. As a result, each member developed certain functions like writing, researching, or editing when developing their respective texts. In the focus groups, students commented that there were moments in which all the members worked equally, sharing ideas and knowledge and completing others' functions without assuming particular roles. In the pre-writing stage, the groups outlined and drafted their first version using Microsoft Word OneDrive (Mw), which led to reaching a consensus by exchanging and organizing ideas. Some of the members of each team researched information to gather enough evidence to support their texts while others were in charge of writing and uploading their outlines and drafts in their MW shared document. During the writing stage, teams also used Mw to review the other team's draft by leaving comments using the comment feature in Word. Afterwards, groups checked each other's comments, corrected their mistakes, and made final edits to their respective texts. YouTube was another tool implemented by the teacher to create a video providing feedback to each group. Finally, in the post-writing stage, students posted their final text to their blogs and wrote a reflection on the process of writing collaboratively. Regarding the use of web 2.0 tools, teacher explained that Mw is software that allows students to write, edit, and make comments using a variety of functions. Certainly, the majority of the students commented that Mw was an essential tool to accomplish the writing task as a team. The teacher also stated that he creates YouTube videos to clarify certain points discussed in class by creating short tutorials. Regarding the use of blogs, the teacher said that students create a blog to upload the final products throughout the course; in fact, during the study students admitted that they enjoyed publishing their texts after having worked in teams. Through the survey and focus groups students expressed that they liked to write as a team because it was useful to share opinions and learn from their teammates; however, for others it was challenging at times to organize their ideas and reach an agreement. Therefore, the implementation of web 2.0 tools in the classroom encouraged students to write collaboratively with the help of their classmates by providing them the opportunity to apply the necessary tools for particular purposes.

\section{Student and Educator Reflections of EP}

As a student, the process of doing my research (as a form of exploratory practice) became easier with the support of my tutor through a variety of ways. While I collected data and analyzed it, I had periods of doubts, but I had the opportunity to solve them by sharing them with my tutor. In the tutoring sessions, we talked about my uncertainties in depth and the tutor gave me suggestions about how to solve them. Nevertheless, as the participant of my study and the tutor for my thesis seminar class were the same person, sometimes it was challenging to separate and comprehend what information came from the tutor and which information came from the participant. Technology was also another way the tutor used to explain and answer my doubts. The tutor was accessible by leaving messages in different platforms like Engrade and Facebook, which made me feel like I had the support that I needed. Every tutoring session was recorded and uploaded to YouTube which was a useful strategy that allowed me to review the video by pausing or repeating it, so to better understand the feedback. Moreover, using Mw online was a way for us to better communicate with each other. For instance, I uploaded my drafts, the tutor made corrections, and I followed up with comments, and so on. All of this helped me to better understand how to do research, putting into practice the knowledge that I have acquired during the whole major. 


\section{Educator Reflection}

Since the objectives of this course were to have learners conduct their own research, the principles that support EP were already a good match for this type of course. The quality of life principle was met as the student researcher had to begin by defining a researchable problem, which in this case was related to the lack of collaborative interactions when writing academic papers using information and communication technologies (ICTS). The learner had spent an entire previous semester in two separate classes (i.e., academic writing and applied linguistic courses) investigating the problem that would become the focus of her research in thesis seminar the following semester. Additionally, during the first four weeks of the thesis seminar course, the learner continued to work on the literature review where she continued framing and reframing the problem that aligned to an overall theoretical framework. In a class of this type, invariably both the learner and I, her tutor, are collectively developing understandings as we meet and discuss each week her study. Much of what we discuss also involves the learner reaching out to other educators, students, administrators, and colleagues that might have a vested interest in the student's research. Having interactions with actual actors in the field allow the learner to become more interdependent as this new leadership role provides vital networking skills that underpin the profession. Learners as new instructional leaders yield valuable information to those educational stakeholders who might benefit from such information. One of the benefits of having gone through this process of systematically collecting data and analyzing it is how EP can be used again in the future as the learner gains more experience and encounters new problems to confront.

\section{Conclusion}

Exploratory practice (EP) complements one's overall instructional design by creating an educative experience around student-teacher negotiation, which stems from the learners' needs, interests, and learning preferences. Students taking thesis seminar sought to appropriate content that matches their needs, interests, and learning preferences vis $\grave{a}$ vis an inquiry -or problem-based learning project- a concept that applies to most classroom contexts. Modifying Allwright \& Lenzuen's (1997) definition then, one can see how EP might provide an alternative or complementary instructional design for various classroom settings:

EP is a name given to a sustainable way of carrying out classroom investigations which provide teachers learners with a systematic framework within which to define areas they wish to explore, to refine their thinking about them, and to investigate them further using classroom activities (as cited in Zhang, 2004: 332).

EP provides the means for students to systematically collect, analyze, and report on data quite a different approach to the more traditional means of content delivery that places content $a$ priori the educative experience. EP is not a replacement, but offers an effective, efficient, and engaging complement to one's pedagogical arsenal, and one that embraces the art of assisting a learner's discovery during the educative experience.

\section{References}

Hanks, J. (2015). 'Education is not just teaching': Learner Thoughts on Exploratory Practice. ELT Journal 69(2), 117-128.

Mireles, F. (2015). Web 2.0 tools: Teaching Resources to Promote Collaborative Writing. (Undergraduate thesis). México: Universidad Autónoma de Aguascalientes.

Stewart, B. (2015). Thesis Seminar [Google Sites]. Retrieved on July 21, 2015 from: https:// sites.google.com/site/thesisseminar1/

Wiggins, G. \& McTighe, J. (2005). Understanding by design. Alexandria, VA: ASCD.

Zhang, R. (2004). Using the Principles of Exploratory Practice to Guide Group Work in an Extensive Reading Class in China. Language Teaching Research, 8(3), 331-345. 